\title{
Top 20 translational researchers of 2014
}

\author{
Brady Huggett \& Kathryn Paisner
}

Our ranking of biotech's top translational researchers (Table 1) is based on patent analytics firm IP Checkups examination of 2014's most active scientists for patenting. The table also includes each researcher's most-cited patent from the prior five years and their $\mathrm{H}$ index (calculated to measure the impact of a scientist's body of

published work; higher $=$ more impact). Table 2 lists the most-cited patents overall from the 2010-2014 period, with inventor. Figure 1 breaks the 50 most-cited patents from 2010-2014 into area of focus, revealing, in particular, the rising interest in genotyping and sequencing technologies.

\section{Table 1 Top 20 researchers in 2014}

\begin{tabular}{|c|c|c|c|}
\hline Inventor/first assignee & $\begin{array}{l}\text { Patents } \\
\text { granted } \\
2014\end{array}$ & 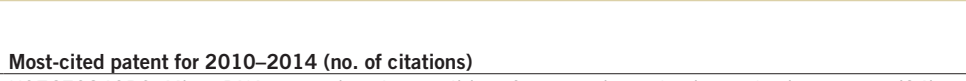 & $\mathrm{H}$ index ${ }^{\mathrm{a}}$ \\
\hline Carlo M. Croce/Ohio State University & 29 & US7670840B2: Micro-RNA expression abnormalities of pancreatic, endocrine and acinar tumors (34) & 187 \\
\hline George Calin/Ohio State University & 18 & US7670840B2: Micro-RNA expression abnormalities of pancreatic, endocrine and acinar tumors (34) & 83 \\
\hline $\begin{array}{l}\text { Thomas H. Tuschl/Rockefeller University; University of } \\
\text { Massachusetts; Whitehead Institute; Massachusetts Institute of } \\
\text { Technology; Max-Planck-Gesellschaft }\end{array}$ & 17 & US7772389B2: Anti-microRNA oligonucleotide molecules (3) & 85 \\
\hline Richard D. DiMarchi/Indiana University & 15 & US8454971B2: Glucagon/GLP-1 receptor co-agonists (3) & 44 \\
\hline Peter G. Schultz/Scripps Research Institute & 15 & US7642085B2: Protein arrays (11) & 113 \\
\hline Feng Zhang/Broad Institute & 13 & US8697359B1: CRISPR-Cas systems and methods for altering expression of gene products (14) & 42 \\
\hline Said M. Sebti/University of South Florida & 11 & US8435959B2: Effective treatment of tumors and cancer with triciribine and related compounds (3) & 61 \\
\hline Stefano Volinia/Ohio State University & 11 & $\begin{array}{l}\text { US8148069B2: MicroRNA-based methods and compositions for the diagnosis, prognosis and treatment } \\
\text { of solid cancers ( } 2 \text { ) }\end{array}$ & 74 \\
\hline Stephen R. Quake/University of North Carolina, Chapel Hill & 10 & US7833708B2: Nucleic acid amplification using microfluidic devices (61) & 65 \\
\hline Surinder Pal Singh/CSIRO & 10 & US7807849B2: Synthesis of long-chain polyunsaturated fatty acids by recombinant cells (23) & 26 \\
\hline Jin Q. Cheng/University of South Florida & 10 & US8435959B2: Effective treatment of tumors and cancer with triciribine and related compounds ( 3 ) & 60 \\
\hline $\begin{array}{l}\text { Phillip D. Zamore/University of Massachusetts; Whitehead Institute; } \\
\text { Massachusetts Institute of Technology; Max-Planck-Gesellschaft }\end{array}$ & 10 & US7691995B2: In vivo production of small interfering RNAS that mediate gene silencing (42) & 68 \\
\hline Bert Vogelstein/Johns Hopkins University & 10 & US7824889B2: Digital amplification (19) & 216 \\
\hline Kenneth W. Kinzler/Johns Hopkins University & 10 & US7824889B2: Digital amplification (19) & 165 \\
\hline Sang Yup Lee/KAIST & 10 & $\begin{array}{l}\text { US7670831B2: Conductive carbon nanotubes dotted with metal and method for fabricating a biosensor } \\
\text { using the same (8) }\end{array}$ & 81 \\
\hline David Baltimore/CalTech & 10 & $\begin{array}{l}\text { US7737124B2: Method for expression of small antiviral RNA molecules with reduced cytotoxicity within } \\
\text { a cell (6) }\end{array}$ & 170 \\
\hline James M. Wilson/ University of Pennsylvania & 10 & $\begin{array}{l}\text { US7790449B2: Adeno-associated virus (AAV) serotype } 8 \text { sequences, vectors containing the same and } \\
\text { uses (11) }\end{array}$ & 125 \\
\hline Robert S. Langer/Children's Medical Center Corp.; Harvard & 8 & US7727969B2: Controlled release nanoparticle having bound oligonucleotide for targeted delivery (27) & 213 \\
\hline David L. Kaplan/Tufts University & 8 & US7842780B2: Silk fibroin materials and use thereof (33) & 93 \\
\hline Karl Deisseroth/Stanford University & 8 & US8398692B2: System for optical stimulation of target cells (12) & 88 \\
\hline
\end{tabular}

aH index supplied by researcher, pulled from Google Scholar or calculated through Thomson Reuters Web of Science. CSIRO, Commonwealth Scientific and Industrial Research Organisation, Australia; KAIST, formerly Korea Advanced Institute of Science and Technology, South Korea.

\section{Table 2 Most-cited patents, 2010-2014}

Patent no.: title

US7785790B1: Replica amplification of nucleic acid arrays

US8112142B2/USRE43282E1 $1^{\mathrm{a}}$ : Assessing the condition of a joint and devising treatment

US7932034B2: Heat and $\mathrm{pH}$ measurement for sequencing of DNA

US7888013B2: Method of analyzing DNA sequence using field-effect device, and base sequence analyzer

US7833708B2: Nucleic acid amplification using microfluidic devices
Inventor/assignee(s)/applicant(s)

Church, George M.; Mitra, Robi D./Harvard University

Alexander, Eugene J.; Andriacchi, Thomas P.; Lang, Philipp;

Steines, Daniel/Stanford University

Esfandyarpour, Hesaam; Ronaghi, Mostafa/Stanford University

Miyahara, Yuji; Sakata, Toshiya/National Institute for Materials Science (Japan)

Enzelberger, Markus M.; Hansen, Carl L.; Liu, Jian; Quake, Stephen R.; Ma, Chiem/California Institute of Technology

\begin{tabular}{cc} 
Publication year & Patent citations, end of $\mathbf{2 0 1 4}$ \\
\hline 2010 & 96 \\
2012 & 95 \\
\hline 2011 & 86 \\
\hline 2011 & 85 \\
\hline
\end{tabular}

2010

apatent reexamination.

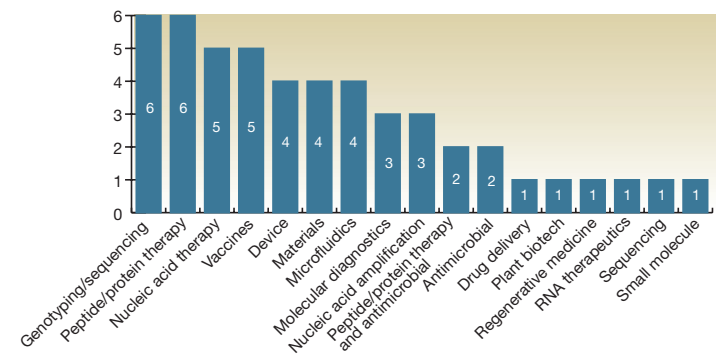

Figure 1 Focus area for 50 most-cited patents, 2010-2014.

\section{First Rounders Podcast: Stanley Crooke \\ Stan Crooke is the founder, chairman and CEO of Isis Pharmaceuticals. Nature Biotechnology spoke with Crooke about his troubled youth, the crests and valleys of antisense, and the skills needed to be a good leader. \\ http://www.nature.com/nbt/podcast/index.html}

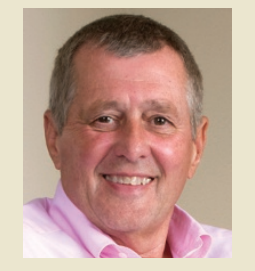

Brady Huggett is business editor at Nature Biotechnology.

Kathryn Paisner is director of research and analytics at IP Checkups,

Berkeley, California, USA.e-mail:kpaisner@ipcheckups.com 